\title{
LOW WATER TEMPERATURE AND ITS EFFECTS ON STRESS RESPONSE OF GREY MULLETS Mugil cephalus ACCLIMATED IN FRESHWATER
}

\author{
Vitas Atmadi Prakoso"\#, Jojo Subagja"), and Young Jin Chang"') \\ ") Research and Development Institute for Freshwater Aquaculture \\ Department of Marine Bio-materials and Aquaculture, Pukyong National University, Busan, Korea
}

(Received 2 February 2015; Final revised 23 March 2015; Accepted 8 June 2015)

\begin{abstract}
Grey mullet (Mugil cephalus) can adapt to saline and freshwater. Although belonged to euryhaline species, but information regarding their stress response on low temperature. Environmental disturbance such as low water temperature may effect their physiological condition. These information can be useful for aquaculture development of this species in freshwater. Therefore, the purpose of study was to investigate the effects of low water temperature on the stress response of grey mullets Mugil cephalus acclimated in freshwater. The blood samples of experimental fish (TL: $28.2 \pm 1.1 \mathrm{~cm}$, BW: 198.6 $\pm 25.9 \mathrm{~g}$ ) were collected during winter season when the water temperature of controlled rearing system was stable at $25^{\circ} \mathrm{C}$ and uncontrolled rearing system slowly dropped until $12^{\circ} \mathrm{C}$. Their stress response on both rearing systems was observed. The results showed that low temperature affected to lower the behavior activity and increase the stress response of grey mullets. The breath frequency of grey mullet regarding their opercular movement at $12^{\circ} \mathrm{C}$ was $74-97$ breath/min., while at $25^{\circ} \mathrm{C}$ it was $95-114$ breath $/ \mathrm{min}$. Hematocrit $(\mathrm{Ht})$ and hemoglobin $(\mathrm{Hb})$ were shown higher values of $43.5 \%$ and $9.5 \mathrm{~g} / \mathrm{dL}$, respectively at $25^{\circ} \mathrm{C}$ than $12^{\circ} \mathrm{C}(28.0 \%$ and $7.1 \mathrm{~g} / \mathrm{dL}$, respectively). The tendencies of cortisol and glucose level increased with the lowering temperature, showing higher value of $264.8 \mathrm{ng} / \mathrm{mL}$ and $35.5 \mathrm{mg} / \mathrm{dL}$ in $12^{\circ} \mathrm{C}$ than $5.5 \mathrm{ng} / \mathrm{mL}$ and $32.7 \mathrm{mg} / \mathrm{dL}$ in $25^{\circ} \mathrm{C}$. The chemical properties of blood in grey mullets showed same tendency comparing between $12^{\circ} \mathrm{C}$ and $25^{\circ} \mathrm{C}$, there was no significant different between each temperature, except for chloride $(\mathrm{P}<0.05)$. Chloride value was higher at $25^{\circ} \mathrm{C}$, while other blood components such as osmolality, sodium, potassium, and magnesium were showing no significant differences. However, the results showed lower values at $12^{\circ} \mathrm{C}$ in every blood components, except for chloride. In conclusion, lowering water temperature to $12^{\circ} \mathrm{C}$ had impact as stressor to the behavior and stress response of grey mullets acclimated in freshwater.
\end{abstract}

KEYWORDS: temperature, stress response, grey mullet, Mugil cephalus, freshwater

\section{INTRODUCTION}

Blood parameters can be one of the methods to determine the stress response of fish. Environmental condition is one of the main reasons which affecting the stress of fish. Many authors investigated the stress response of fish according to the environmental condition, including freshwater fish and marine fish (Tapia et al., 2012; Chang \& Hur, 1999; Chen et al., 1995; Min et al., 2010). According to numerous studies, the most popular approaches for evaluating physiological responses of fish to environmental disturbances are measurements of plasma cortisol, glucose, lactate, chloride (and other ions), and osmola-

\# Corresponding: Research and Development Institute for Freshwater Aquaculture. Jl. Sempur No. 1, Bogor 16151, Indonesia. Tel.: + (0251) 8313200

E-mail: vitas.atmadi@gmail.com lity, and various hematological features (Barton et al., 2002).

The grey mullet (Mugil cephalus) is a euryhaline species which can can adapt to marine and freshwater environments (Saleh, 2008). As the advantage of their osmoregulation ability, grey mullet often cultured together with other species (polyculture) in brackish and freshwater semi-intensive fishponds. In Asian and Mediterranean markets, mullet roe is a highpriced product, supplementing the fish flesh. These commercial and environmental attributes make mullet an important candidate for domestication (Aizen et al., 2005). Although this species can tolerate to freshwater, more information were needed to investigate their response on low water temperature. The temperature range of distribution of Mugil cephalus is known to be $12^{\circ} \mathrm{C}-25^{\circ} \mathrm{C}$, but the lower limit of temperature controlling the natural distribution of the 
species seem to be between $16^{\circ} \mathrm{C}$ and $18^{\circ} \mathrm{C}$. Their temperature tolerance was stretchable, depending on the natural temperature at their geographical locations (Oren, 1981). The information can be useful for aquaculture development of this species in freshwater. Thus, oxygen consumption data will be useful in aquaculture management of freshwater-acclimated grey mullets. The purpose of this study was to observe the effects of low water temperature on the stress response of grey mullets acclimated in freshwater.

\section{MATERIALS AND METHODS}

Fish (grey mullets) were acclimated into freshwater for six months and fed two times a day at $2 \%$ of its body weight with commercial feed. Fish were divided into two rearing systems, one with temperature controlled system $\left(25^{\circ} \mathrm{C}\right)$, and the other is without temperature controlled system $\left(12^{\circ} \mathrm{C}\right)$. These experiments were conducted on indoor recirculating system by using 10 fish in fiber tank (diameter: 50 $\mathrm{cm}$; water level: $100 \mathrm{~cm}$ ) with two replications. The experiments were conducted to measure the effects of water temperature at $12^{\circ} \mathrm{C}$ (treatment) and $25^{\circ} \mathrm{C}$ (control) on the stress response of grey mullets acclimated in freshwater. The size of fish used in these experiments was about $28.2 \pm 1.1 \mathrm{~cm}$ in total length and $198.6 \pm 25.9 \mathrm{~g}$ in body weight.

In this study, blood samples were analyzed to determine the stress response of grey mullets. At the time during winter season when the water temperature of uncontrolled rearing system slowly dropped until reach to $12^{\circ} \mathrm{C}$, their stress response on both rearing systems was observed. Blood samples were collected from three fish in each rearing systems. Before collecting blood, fish were starved for 24 hours. Fish were anesthetized using 2-phenoxyethanol and blood samples were collected from caudal part of fish using heparinized syringes ( $1 \mathrm{~mL}$ each samples), centrifuged (12,000 rpm, $5 \mathrm{~min}$.), and stored in deep freezer until analyzing blood properties of hematocrit $(\mathrm{Ht})$, hemoglobin $(\mathrm{Hb})$, glucose, plasma cortisol, osmolality, sodium, chloride, potassium, and magnesium. Hematocrit $(\mathrm{Ht})$ was analyzed by using microhematocrit reader (Micro Hematocrit Reader, Hawksley). Hemoglobin (Hb), glucose, sodium, chloride, potassium, and magnesium were analyzed by using Chemical Analyzer (Fujifilm Dri-Chem 3500i, Japan). Plasma cortisol was analyzed by Enzyme Immonoassay (EIA) using Cortisol EIA kit (Oxford Biomedical Research, USA), while plasma osmolality was examined with Vapor Pressure Osmometer (Vapro 5520; Wescor Co., USA). The behavior of the fish was also observed during experiment, including their movements in the water. Collected data were analyzed by PASW Statistics 18.

\section{RESULTS AND DISCUSSION}

\section{Behavioral Response of The Fish}

The fish behavior was investigated by visual observation during experiments. In each experiment showed different responses based on their activity and breath frequency. At low water temperature $\left(12^{\circ} \mathrm{C}\right)$, the activity of grey mullets was lower than the fish reared at $25^{\circ} \mathrm{C}$. It also obviously can be seen by their opercular movement. The opercular movement of fish at low water temperature was slower compared to the fish reared in the rearing system with temperature controlled $\left(25^{\circ} \mathrm{C}\right)$. The breath frequency of grey mullet regarding their opercular movement at $12^{\circ} \mathrm{C}$ was $74-97$ breath/min., while at $25^{\circ} \mathrm{C}$ it was $95-114$ breath $/ \mathrm{min}$. It showed that low water temperature as the stressor had clear impact to the activity of grey mullets. At the stress conditions caused by low water temperature, it triggered the modifications in oxygen consumption and energy demands (Morgan \& Iwama, 1991).

\section{Blood Properties}

As shown in Table 1, it showed significant differences in hematocrit $(\mathrm{Ht})$ and hemoglobin $(\mathrm{Hb})$ levels between treatment and control $(\mathrm{P}<0.05)$. The change of water temperature has tendency to decrease the hematocrit and hemobglobin levels (Table 1). The grey mullets reared at low water temperature showed slower opercular movement due to the stress condition. If it continuously happened, it might be lethal for grey mullets.

At this present study, the results of blood properties indicated that water temperature affected to the stress response of grey mullets. It can be obtained from their blood properties results. Hematocrit $(\mathrm{Ht})$ and hemoglobin $(\mathrm{Hb})$ values were lower at $12^{\circ} \mathrm{C}$ than $25^{\circ} \mathrm{C}$. Changes in $\mathrm{Ht}$ and $\mathrm{Hb}$ according to environment condition were also reported by Chang \& Hur (1999). As the effect of thermal acclimatization, it expressed as the change of oxygen consumption after cold-acclimation (Graham \& Farrell, 1990).

Table 1. Physical properties of grey mullets' blood during experiments

\begin{tabular}{lrr}
\hline \multirow{2}{*}{ Component } & \multicolumn{2}{c}{ Experiments } \\
\cline { 2 - 3 } & \multicolumn{1}{c}{$\mathbf{1 2}^{\mathbf{o}} \mathrm{C}$} & \multicolumn{1}{c}{$\mathbf{2 5 ^ { \circ } \mathrm { C }}$} \\
\hline Hematocrit $(\%)$ & $18.9 \pm 5.4^{\mathrm{a}}$ & $26.8 \pm 0.2^{\mathrm{b}}$ \\
Hemoglobin $(\mathrm{g} / \mathrm{dL})$ & $4.2 \pm 0.6^{\mathrm{a}}$ & $6.4 \pm 0.2^{\mathrm{b}}$ \\
\hline
\end{tabular}

Note:

Values are the mean $\pm S D(n=3)$. The mean values with different superscript are significantly different $(P<0.05, t$-test) 
The results of blood parameters showed that cortisol on grey mullets at $25^{\circ} \mathrm{C}$ was significantly lower than $12^{\circ} \mathrm{C}(\mathrm{P}<0.05)$. The blood parameters such as plasma osmolality and glucose were not significantly different between $12^{\circ} \mathrm{C}$ and $25^{\circ} \mathrm{C}(\mathrm{P}>0.05)$. Cortisol levels increased with the lowering temperature, it showed $264.8 \mathrm{ng} / \mathrm{mL}$ in $12^{\circ} \mathrm{C}$ and $5.5 \mathrm{ng} / \mathrm{mL}$ in $25^{\circ} \mathrm{C}$, while glucose at low temperature showed $35.3 \mathrm{mg} /$ $\mathrm{dL}$ in $12^{\circ} \mathrm{C}$ and $32.7 \mathrm{mg} / \mathrm{dL}$ in $25^{\circ} \mathrm{C}$ (Table 2).

Stress is mediated through neuronal and endocrine pathways, known as the primary response, following initial perception of the stressor, which in turn influence secondary physiological features and whole-animal performance characteristics in the fish. Initially, the stress response is considered adaptive, one designed to help the fish overcome the disturbance and regain a homeostatic or normal state (Barton et al., 2002). If the stressor's intensity is longlasting, the physiological response of fish may be compromised or influenced their health and well-being, or may become maladaptive (Barton \& Iwama, 1991).

Cortisol as one of the stress indicator was assigned to stimulate the liver gluconeogenesis and elevating blood sugar levels (Wedemeyer et al., 1990). The hypothalamus-pituitary-interrenal activity was triggered by stressor, which resulting in cortisol secretion (Perry \& Reid, 1993) and increased the blood glucose (Tomasso et al., 1980). In this study, low water temperature as a stressor tend to increase the stress of grey mullets. It was also related to behavior and breath frequency of grey mullets, as the results showed low activity at low water temperature. The blood properties of grey mullets also showed clear impact of temperature.

The results of chemical properties of blood in grey mullets showed same tendency compare between $12^{\circ} \mathrm{C}$ and $25^{\circ} \mathrm{C}$, there was no significant different between each temperature, except for chloride $(\mathrm{P}<0.05)$. Chloride value was higher at $25^{\circ} \mathrm{C}$, while other blood components such as osmolality, sodium, potassium, and magnesium showed no significant differences.

Table 2. Stress indicator paramaters of grey mullets' blood during experiments

\begin{tabular}{lrr}
\hline \multirow{2}{*}{ Component } & \multicolumn{2}{c}{ Experiments } \\
\cline { 2 - 3 } & \multicolumn{1}{c}{$\mathbf{1 2}^{\mathbf{0}} \mathrm{C}$} & \multicolumn{1}{c}{$\mathbf{2 5}^{\mathbf{}} \mathrm{C}$} \\
\hline Plasma cortisol $(\mathrm{ng} / \mathrm{mL})$ & $264.8 \pm 76.8^{\mathrm{b}}$ & $5.5 \pm 2.3^{\mathrm{a}}$ \\
Glucose $(\mathrm{mg} / \mathrm{dL})$ & $35.3 \pm 2.1^{\mathrm{a}}$ & $32.7 \pm 3.5^{\mathrm{a}}$ \\
\hline
\end{tabular}

Note: Values are the mean $\pm \operatorname{SD}(n=3)$. The mean values with different superscript are significantly different $(P<0.05$, $t$-test)
However, the results showed lower values at $12^{\circ} \mathrm{C}$ in every blood components, except for potassium (Table 3).

Stress will make impact to fish metabolism and growth, immune systems, reproduction, and their behavior. Stress can be identified by the loss of blood ions such as sodium, chloride, and total osmolality. While for marine fishes, stress may exhibit an increase in ion influx, osmolality, and loss of water across the gills (Wendelaar Bonga, 1997; Cech, 2000). Change of blood ions and plasma osmolality can be indication of hydromineral imbalance which can possibly affect to the disturbance of fish osmoregulatory system (Barton et al., 2002).

The acclimation temperature of fish likely contributed for the elevations of blood ions and cortisol. Temperature, salinity, nutritional state, water quality, time of day, light, and fish density were the environmental nonstress factors that can affect the stress response of fish (Barton, 1997). Rapid decreases in water temperature may result in a number of physiological, behavioural, and fitness consequences for fishes termed "cold-shock". Cold-shock stress occurs when a fish has been acclimated to a specific water temperature or range of temperatures and is subsequently exposed to a rapid decrease in temperature, resulting in a cascade of physiological and behavioural responses and, in some cases, death (Donaldson et al., 2008).

Exposure to environmental stressors is a concern to biologists and managers because of the possible detrimental effects on important fish performance features such as metabolism and growth, disease resistance, reproductive capacity, and ultimately the health, condition, and survival of fish populations. If the stressor is overly severe or long-lasting, however, the fish may no longer be able to cope with it and enters a maladaptive or distressed state leading

Table 3. Chemical properties of grey mullets' blood during experiments

\begin{tabular}{lcc}
\hline \multirow{2}{*}{ Component } & \multicolumn{2}{c}{ Experiments } \\
\cline { 2 - 3 } & $\mathbf{1 2}^{\mathbf{0}} \mathrm{C}$ & $\mathbf{2 5}^{\mathbf{0}} \mathrm{C}$ \\
\hline Osmolality $(\mathrm{mOsm} / \mathrm{kg})$ & $340.3 \pm 39.8^{\mathrm{a}}$ & $350.0 \pm 35.4^{\mathrm{a}}$ \\
Sodium $(\mathrm{mEq} / \mathrm{L})$ & $134.0 \pm 4.0^{\mathrm{a}}$ & $139.3 \pm 7.2^{\mathrm{a}}$ \\
Chloride $(\mathrm{mEq} / \mathrm{L})$ & $132.0 \pm 6.0^{\mathrm{a}}$ & $150.7 \pm 12.2^{\mathrm{b}}$ \\
Potassium $(\mathrm{mEq} / \mathrm{L})$ & $2.5 \pm 0.4^{\mathrm{a}}$ & $2.4 \pm 0.3^{\mathrm{a}}$ \\
Magnesium $(\mathrm{mg} / \mathrm{dL})$ & $1.1 \pm 0.1^{\mathrm{a}}$ & $1.8 \pm 0.7^{\mathrm{a}}$ \\
\hline
\end{tabular}

Note: Values are the mean $\pm S D(n=3)$. The mean values at the same row with different superscript are significantly different $(\mathrm{P}<0.05, t$-test $)$ 
to a pathological condition or possibly death (Barton et al., 2002). Long-term effects of low temperature on the physiological response of grey mullets were not observed in this study.

The results from this study showed the effect of low water temperature as a stressor was not significantly change the blood ions and osmolality of grey mullets, except in chloride. It seems that the grey mullets were still able to control their blood ions and osmolality at $12^{\circ} \mathrm{C}$, at least not on the long-term exposure. However, generally the values of blood ions and osmolality were lower at $12^{\circ} \mathrm{C}$, which means lower temperature slightly affect the blood properties of grey mullets. McCormick et al. (2000) stated that water temperature can affect the activity of gill $\mathrm{Na}^{+}-\mathrm{K}^{+}$ATPase. Generally at lower temperature, it reduced the enzyme activity. Another statement from Mackie et al. (2005) suggested that $\mathrm{Na}^{+}-\mathrm{K}^{+}$ATPase is involved in chloride cell secretion by providing an electrochemical gradient for $\mathrm{Na}^{+}$and $\mathrm{Cl}^{-}$movement between blood and water.

Acclimation to low temperature or cold shock lead to failure in osmotic regulation such that fish in saltwater gained plasma electrolytes while freshwateracclimated fish losed ions (Donaldson et al., 2008).

\section{CONCLUSION}

From the results of this study, lowering water temperature to $12^{\circ} \mathrm{C}$ had impact as stressor to the behavior and stress response of grey mullets Mugil cephalus acclimated in freshwater. According to the results of blood properties, grey mullets acclimated in freshwater should be avoided from low water temperature or cold shock to prevent from the stress or mortality. The effects of long-term acclimation at low temperature of grey mullets acclimated in freshwater should be observed in the further study to analyze their physiological response.

\section{REFERENCES}

Aizen, J., Meiri, I., Tzchori, I., Levavi-Sivan, B., \& Rosenfeld, H. (2005). Enhancing spawning in the grey mullet (Mugil Cephalus) by removal of dopaminergic inhibition. General and Comparative Endocrinology, 142, 212-221.

Barton, B.A. (1997). Stress in finfish: past, present and future: a historical perspective. In Iwama, G.K., Pickering, A.D., Sumpter, J.P., \& Schreck, C.B. (Eds.). Fish stress and health in aquaculture. Society for experimental biology seminar series 62, Cambridge University Press, Cambridge. UK. p. 1-33.

Barton, B.A., \& Iwama, G.K. (1991). Physiological changes in fish from stress in aquaculture with emphasis on the response and effects of corti- costeroids. Annual Review of Fish Diseases, 1, 3-26.

Barton, B.A., Morgan, J.D., \& Vijayan, M.M. (2002). Physiological and condition-related indicators of environmental stress in fish. In Adams, S.M. (Ed.). Biological Indicators of Ecosystem Stress, American Fisheries Society, Bethesda, MD. USA, p. 111148.

Cech, Jr.J.J. (2000). Osmoregulation in bony fishes. In Stickney, R.R. (Ed.). Encyclopedia of Aquaculture. John Wiley and Sons. New York, p. 614-622.

Chang, Y.J., \& Hur, J.W. (1999). Physiological responses of grey mullets (Mugil cephalus) and nile tilapia (Oreochromis niloticus) by rapid changes in salinity of rearing water. Journal of Korean Fisheries Society, 32, 310-316.

Chen, G.R., Sun, L.T., Lee, Y.H., \& Chang, C.F. (1995). Characteristics of blood in common crap, Cyprinus carpio, exposed to low temperature. Journal of Applied Aquaculture, 5, 21-31.

Donaldson, M.R., Cooke, S.J., Patterson, D.A., \& Macdonald, J.S. (2008). Cold shock and fish. Journal of Fish Biology, 73, 1491-1530.

Graham, M.S., \& Farrell, A.P. (1990). Myocardial oxygen consumption in trout acclimated to $5^{\circ} \mathrm{C}$ and $15^{\circ} \mathrm{C}$. Physiology Zoology, 63, 536-554.

Mackie, P., Wright, P.A., Glebe, B.D., \& Ballantyne, J.S. (2005). Osmoregulation and gene expression of $\mathrm{Na}^{+} / \mathrm{K}^{+}$ATPase in families of Atlantic salmon (Salmo salar) smolts. Canadian Journal of Fish Aquatic Science, 62, 2661-2672.

McCormick, S.D., Moriyama, S., \& Thrandur Bjornsson, B. (2000). Low temperature limits photoperiod control of smelting in Atlantic salmon through endocrine mechanisms. American Journal of Physiological Regulatory, Integrative and Comparative Physiology, 278, 1352-1361.

Min, E.Y., Kim, Y.S., \& Kang, J.C. (2010). Dietary effects of lactic acid bacteria on growth, hematological and immune response of grey mullets, Mugil cephalus. Journal of Fish Pathology, 23, 343355.

Morgan, J.D., \& Iwama, G.K. (1991). Effects of salinity on growth, metabolism, and ion regulation in juvenile rainbow and steelhead trout (Oncorhynchus mykiss) and fall chinook salmon (Oncorhynchus tshawytscha). Journal of Fisheries Aquatic Science, 48, 2083-2094.

Oren, O.H. (1981). Aquaculture of grey mullets. Cambridge University Press. Cambridge, 507 pp.

Perry, S.F., \& Reid, S.D. (1993). $\beta$-Andrenergic signal transduction in fish: interactive effects of catecholamines and cortisol. Fisheries Physiology and Biochemistry, 11, 195-203.

Tapia, P.J., Puebla, M.C., Munoz, A., Rojas, E., Marchant, 
C.M., Cornejo, M.A., Futagawa, M., \& Small, B.C. (2012). Evaluation of the cortisol stress response in a marine Perciform fish, the San Pedro Oplegnathus insignis. North American Journal of Aquaculture, 74, 438-442.

Tomasso, J.R., Davis, K.B., \& Parker, N.C. (1980). Plasma corticosteroid and electrolyte dynamics of hybrid striped bass (white bass $\times$ striped bass) during netting and hauling stress. Proceeding of World Mariculture Society, 11, 303-310.

Wedemeyer, G.A., Barton, B.A., \& McLeay, D.J. (1990). Stress and acclimation. In Schreck, C.B., \& Moyle, P.B. (Eds.). Methods for Fish Biology. American Fisheries Society, p. 491-527.

Wendelaar Bonga, S.E. (1997). The stress response in fish. Physiological Reviews, 77, 591-625. 